\title{
TOLAK BALAK: \\ Tinjauan atas Ritual Atib Ko Ambai di Rokan Hulu
}

\author{
Syahrun Nizom \\ Jurusan Studi Agama-Agama, Fakultas Ushuluddin, UIN SUSKA Riau \\ Email: kiyainizom@gmail.com
}

\author{
Abu Bakar \\ Jurusan Studi Agama-Agama, Fakultas Ushuluddin, UIN SUSKA Riau \\ Email: abu.ghofur@,uin-suska.ac.id
}

\author{
Abdul Ghofur \\ Jurusan Studi Agama-Agama, Fakultas Ushuluddin, UIN SUSKA Riau \\ Email: abd.ghofur@uin-suska.ac.id
}

\begin{abstract}
Abstrak
Dalam tradisi Ritual Atib Ko Ambai (tradisi tolak bala) terdapat beberapa bal penting yang terbagi atas dua tradisi ritual itu sendiri yaitu; Tradisi Ritual Atib Ko Ambai dalam acara ritual tolak bala, serta tradisi riarah makam datuk. rambai. Dalam acara Ritual Tolak Bala dilaksanakan sekali dalam setiap tabunya pada saat hari keempat idul fitri. Pelaksanaan dimulai dari pukul 8 pagi bingga selesai, dengan tujuan untuk. menolak bala serta membuang segala bentuk bal-hal buruk dan juga penyakit ke laut. Sedangkan tradisi ziarah makam Datuk. Rambe dalam membayar niat/nazar (sebagai masyarkat yang berniat) Masyarakat yang datang dari berbagai daerah Kabupaten Rokan Hilir tersebut bernazar untuk. datang ke makam Datuk. Rambe dengan niat "Jika nanti dia sembuh dari penyakit yang dideritanya, maka ia akan mengadakan syukuran atas hal itu. Kemudian akan kembali ke makam Datuk rambe. untuk berdoa" a serta melakukan tradisi Ziarah Makam Datuk Rambe. Ziarah tersebut terdiri dari beberapa aspek yang tergambar pada nilai sejarah, nilai simbol pada kain putih, nilai keagamaan (Religius), dan Nilai Kekeluargaan.
\end{abstract}

Kata Kunci : Tradisi Ritual Atib Ko Ambai, Pelaksanaan, dan Sistem Nilai

\section{Abstract:}

In the Atib Ko Ambai Ritual tradition (the tradition of rejecting reinforcements) there are several important things which are divided into two ritual traditions themselves, namely; The Atib Ko Ambai Ritual Tradition in the ritual of rejecting reinforcements, as well as the pilgrimage tradition of Datuk Rambai's tomb. The Reject Bala ritual is held once a year on the fourth day of Eid al-Fitr. The implementation starts from 8 in the morning until finished, with the aim of rejecting reinforcements and throwing all forms of bad things and diseases into the sea. While the tradition of pilgrimage to the tomb of Datuk Rambe in paying the intention / vows (as people who intend) The community who came from various areas of Rokan Hilir Regency made a vow to come to Datuk Rambe's grave with the intention "If later he recovers from his illness, then he will hold thanks for that. Then will return to the tomb of Datuk Rambe. to pray and perform the tradition of Pilgrimage to the Tomb of Datuk. Rambe. The pilgrimage consists of several aspects which are reflected in historical values, symbol values on white cloth, religious values (Religious), and family values.

Keywords: waqaf, waqaf for grandchildren, development

\section{PENDAHULUAN}

Persoalan yang di hadapi manusia sangat komplek, seperti hal nya persoalan tsunami, gempa bumi, penyakit dan hama dll, hingga persoalan kehidupan masyarakat sosial manusia tidak bisa lepas dan lari dari persoalan tersebut. Oleh karena itu, menghadapi dan mencari solusinya. Ada banyak cara yang dilakukan oleh manusia, salah satunya berdamai dengan alam melalui pelaksanaan serangkaian ritual atau upacara. Meskipun manusia berada dalam zaman yang serba maju dan canggih, namun cara seperti ini tidaklah ditinggalkan sepenuhnya oleh sebagian kelompok masyarakat. Bagi mereka melaksanakan ritual untuk berdamai dengan alam adalah jalan 
untuk mencapai kehidupan yang damai, aman, tentram, dan sejahtera. Ritual tersebut secara umum bagi masyarakat Riau dikenal dengan istilah "Tolak Bala". Ritual ini dilaksanakan setiap tahun dan telah biasa dilakukan dan telah menjadi tradisi masyrakat setempat di Kecamatan Kubu Kabupaten Rokan Hilir.

Fenomena yang telah diuraikan diatas, membuat penulis tertarik untuk menelitinya, karena tradisi ini sangat penting dilakukan oleh masyarakat Melayu Kubu bahkan boleh dikatakan harus bagi masyarakat Kubu dan dalam pelaksanaannya pun terdapat integrasi ketiga keterampilan yang dimiliki oleh setiap individu sebagai makluk beragama dan bersosial. Hal ini juga menjadi dasar peneliti untuk melakukan penelitian dan mengkaji lebih dalam lagi terkait peristiwa pelestarian tradisi Atib Ko Ambai, dan mengungkapkan suatu kajian menurut pandangan Jurusan Studi Agama-agama yang pada saat ini perlu dikaji secara dalam menurut kosep Agama Islam dan dibudayakan ditengah kehidupan masyarakat, khususnya memiliki makna tersendiri bagi masyarakat Melayu Kubu maka dari itu penulis tertarik untuk menteliti lebih dalam tentang Ritual Atib Ko Ambai (Tradisi tolak bala) di Kecamatan Kubu Babussalam Kabupaten Rokan Hilir.

\section{Konteks Penelitian}

Tulisan ini merupakan hasil penelitian yang dilakukan dalam rangka penyelesaian kuliah di program Sarjana jurusan Studi Agama di Ushuluddin. Untuk Menghindari terjadinya kesalahpahaman terhadap istilah yang penulis pakai dalam penelitian ini, maka penulis perlu menjelaskan beberapa istilah yang di anggap perlu untuk memberikan kejelasan terhadap tulisan ini. Diantaranya sebagai berikut

Pertama, Ritual atau Ritus merupakan aktifitas dari tindakn manusia untuk melakukan kebaktian terhadap Tuhan (Allah subhanahuwataala) bagi umat muslim, atau Dewa-Dewa bagi Agama lain nya,atau roh nenek moyang dan makhluk halus lainya. Biasanya berlansung berulang ulang baik

\footnotetext{
${ }^{1}$ Koentjaraningrat, Beberapa Pokok Antrapologi Sosial, (Jakarta: Dian Rakyat, 1985), hlm. 11.

2 (Wawancara: KH. Ramli, tokoh dari tarikat Naqsabandi, di kediaman nya, desa Sungai Pinang 29-012021).
}

setiap hari, setiap musim, atau kadang-kadang saja. Ritual atau Ritus ini biasanya merupakan tindakan berdoa, bersujut, bersaji, berkorban, makan bersama,menari dan bernyanyi, berposesi, berseni drama suci, berpuasa, bertapa dan bersemedi. ${ }^{1}$

'Atib Ko Ambai adalah Ritual menolak Bala yang memiliki sejarah tersendiri bagi masyarakat kubu. Atib atau Ratib dalam kamus besar bahasa Indonesia berarti puji-pujian atau doa kepada tuhan yang di ucapkan berulang ulang, berdoa dan bezikir kepada Allah subhanahu wa taala. ${ }^{2}$

\section{Asal Usul Nama Datuk Rambe (Syekh Abdullah Pasai)}

Nama Datuk Rambai sebenarnya bukanlah nama asli dari makam yang dianggap keramat tersebut. Adapun nama aslinya adalah Syekh Abdullah Pasai, Nama itu diberikan masyarakat atas dasar adanya sebuah pohon rambai ditempat makam beliau berada. Seperti yang disampaikan oleh Bapak H.Samuel Matwafa (selaku tokoh adat) bahwasanya :

"Istilah dari kata Datok Ambai berawal dari adanyo pohon Rambai yang ada disekita makam beliau . Jadi kalau ada orang ingin berziarah atau membayar niat, maka ornang tersebut datang ke makom syekh Abdullah pasai (datuk rambai) dan di situ mereka membaca yasin tahtim tahlil atau suroh-suroh atau bacaan dzikir lain nya. Maka dari hal itulah makam Teuku Abdullah Pasai ini diberi nama atau julukanya (makom datuk rambai). ${ }^{3}$

Istilah dari kata Datuk Rambai berawal dari adanya pohon rambai yang ada disekitar makam beliau sekarang. Jadi kalau ada orang datang pergi berziarah atau membayar nazar, maka orang itu mengikatkan kain putih ke pohon rambai sebagai simbol bahwa orang itu sudah membayar nazar atau ziarah ke makam Datuk Rambai. Maka dari hal itulah makam Teuku Abdullah Pasai ini diberi nama atau julukan sebagai Datuk Rambai). Datuk Rambai dalam acara ritual tolak bala, serta Tradisi Ziarah Makam Datuk Rambai dalam membayar niat (bernazar).

\footnotetext{
${ }^{3}$ Wawancara: bapak H.Sahmuel Matwafa, (tokoh adat) di rumahnya Desa Simpang Pelita tanggal 25 Januari 2021
} 


\section{Sejarah Pelaksanaan Tradisi Ritual Atib Ko Ambai (Tradisi tolak bala)}

Awal mula Tradisi Ritual Atib Ko Ambai ini yaitu, semenjak beliau memasuki wilayah Kubu Babussalam untuk mengembangkan agama islam. Namun sebelum Beliau datang, terlebih dahulu masyarakat sudah memeluk agama islam semenjak mereka bertempat di daerah tersebut. Tetapi pada waktu itu pendidikan tidak diperhatikan pemuka suku, sehingga sepeninggalan kepala-kepala suku tersebut, anak cucu mereka tidak ada yang berpendidikan baik agama ataupun umum, yang diutamakan pada masa itu adalah pencak silat dan ilmu-ilmu beladiri lainnya, selain ilmu-ilmu mistik yang bersumber Tidak jelas atau dari setan dan iblis.

Menurut sejarah yang tidak tertulis tetapi hal ini dapat diterima kebenarannya, dalam situasi semerawut ini datang pengembara dari Aceh, yang diketuai oleh Teuku Abdullah Pasai karena beliau berasal dari Negeri Pasai/Aceh. Beliau ditemani murid muridnya, diantaranya Syekh Abu Hasan Perlak dan beberapa pengikutnya, mereka ini terdiri dari kaum laki-laki semuanya. Maksud kedatangan pengembara ini adalah untuk mengembangkan ajaran agama Islam yang sebenarnya di Negeri

\section{Sejarah Pelaksanaan Tradisi Ritual Atib Ko Ambai (Tradisi tolak bala)}

Awal mula Tradisi Ritual Atib Ko Ambai ini yaitu, semenjak beliau memasuki wilayah Kubu Babussalam untuk mengembangkan agama islam. Namun sebelum Beliau datang, terlebih dahulu masyarakat sudah memeluk agama islam semenjak mereka bertempat di daerah tersebut. Tetapi pada waktu itu pendidikan tidak diperhatikan pemuka suku, sehingga sepeninggalan kepala-kepala suku tersebut, anak cucu mereka tidak ada yang berpendidikan baik agama ataupun umum, yang diutamakan pada masa itu adalah pencak silat dan ilmu-ilmu beladiri lainnya, selain ilmu-ilmu mistik yang bersumber Tidak jelas atau dari setan dan iblis. ${ }^{4}$
Menurut sejarah yang tidak tertulis tetapi hal ini dapat diterima kebenarannya, dalam situasi semerawut ini datang pengembara dari Aceh, yang diketuai oleh Teuku Abdullah Pasai karena beliau berasal dari Negeri Pasai/Aceh. Beliau ditemani murid muridnya, diantaranya Syekh Abu Hasan Perlak dan beberapa pengikutnya, mereka ini terdiri dari kaum laki-laki semuanya. Maksud kedatangan pengembara ini adalah untuk mengembangkan ajaran agama Islam yang sebenarnya di Negeri Kubu Babussalam. Pada awalnya masyarakat menerima Beliau dan rombongan. Setelah itu mereka tidak mau lagi mengikuti ajaran-ajaran Beliau karena bertentangan dengan apa yang mereka kerjakan saat itu, sehingga terjadi permusuhan antara pengikut-pengikut Teuku Abdullah Pasai dengan masyarakat. Tetapi sebagian kecil masyarakat ada juga yang fanatik dengan ajaran Islam yang di bawa Beliau dikala itu.

Sembilan tahun Beliau bersama muridmuridnya bertempat tinggal di wilayah tersebut, Beliau (Teuku Abdullah Pasai) berpulang ke Rahmatullah. Sebelum meninggal Beliau berwasiat kepada murid muridnya, apabila Beliau meninggal dunia supaya dikebumikan di tempat itu juga. Setelah dilaksanakan fardhu kifayah atas jenazah Beliau, maka dikebumikanlah di tempat itu, yang sekarang bernama Desa Teluk Nilap.

Pada tahun 1888 Tuan Guru Babussalam Syekh Abdul Wahab Rokan mengutus seorang menantu Beliau bernama Tuan Haji Abdul Fattah untuk ziarah ke makam Teuku Abdullah Pasai di Kubu Babussalam (KUBU). Pada waktu itu Sungai Asal tidak dapat dilalui lagi karena sudah tembur (istilah Kubu) yang berarti sudah dangkal dan tidak dapat di jangkau, yang ada sekarang adalah pintasan/terusan. Oleh Syekh Haji Abdul Fattah mengambil suatu keputusan di tempat yang sekarang itulah Beliau dan para jemaahnya berdoa kepada Allah, semoga Negeri Kubu Babussalam (KUBA) selalu dalam lindungan Allah, karena begitulah pesan dari Tuan Guru Syekh Abdul Wahab Rokan.

\footnotetext{
${ }^{4}$ Wawancara; Datuk Kamalul (tokoh suku melayu) di rumahnya desa Rantau Panjang Kiri (Rtp.kiri), tanggal 19 januari 2021
} 


\section{Awal Mula Tradisi Ziarah Makam Datuk Rambai}

Tradisi ziarah ini dahulu bermula pada saat Tuan Guru Babussalam Syekh Abdul Wahab Rokan mengutus seorang menantu Beliau bernama Tuan Haji Abdul Fattah untuk ziarah ke makam Teuku Abdullah Pasai di Kubu Babussalam. Beliau dan para jemaahnya berdoa kepada Allah dengan berkat kesholehan syekh abdullah pasai (bertawassul). Tawassul adalah meminta kepada Allah dengan perantara. Baik itu dengan perantara amal sholeh atau dengan perantara orang-orang sholeh. Dalil nya: ( QS. AlMaidah; 35 "wahai orang-orang yang beriman bertakwalah kepada Allah dan meminta lah kepada nya dengan perantara atau wasilah, dan berjibat lab di jalannya agar kalian beruntung"). semoga Negeri Kubu Babussalam selalu dalam lindungan Allah dan dijauhkan dari segala macam bala, serta wabah penyakit yang melanda daerah kubu Babusslam saat itu.

\section{Tradisi Atib Ko Ambai Dalam Acara Ritual Tolak Bala}

Tradisi ini biasa dilaksanakan pada saat hari keempat Idul Fitri yang dimulai dari pukul 8 pagi hingga selesai, dengan tujuan tidak lain dan tidak bukan hanya untuk menolak bala serta membuang segala bentuk hal hal buruk dan juga wabah penyakit yang ada dikampung tempat mereka tinggal. Adapun hal-hal penting yang dapat dijelaskan dalam proses pelaksanaan tradisi tersebut, yaitu diantaranya sebagai berikut:

Pertama, Tujuan Tradisi Ziarah Makam Datuk Rambai dalam Acara Ritual Tolak Bala. Pada masamasa terdahulu ritual tolak bala ini hanya diselenggarakan dan dilaksanakan oleh masyarakat pada saat-saat tertentu saja, yakni dengan tujuan menolak bala atau wabah penyakit yang datang melanda kampung mereka, seperti mana yang sudah disinggung dimuka sebelumnya.

Namun disaat sekarang ini ritual tolak bala tersebut lebih tertib dalam pelaksanaannya, yaitu dilaksanakan pada setiap tahunnya dihari keempat Idul Fitri. Hal ini juga tidak terlepas dari campur tangan dan perhatian pemerintah setempat dalam melestarikan serta mengatur ketertiban ritual tolak

\footnotetext{
5 Wawancara; Datuk Kamalul (Tokoh suku melayu) dilakukan Pada Tangal 19 Januari 2021
}

bala dengan membentuk kepanitiaan dalam pelaksanaannya. Dalam hal serupa, keterangan mengenai tujuan diadakannya acara ritual tolak bala ini juga disampaikan oleh salah satu dari narasumber yaitu Datuk Kamalul (selaku tokoh masyarakat dan kepala desa) yang telah diwawancarai dan didapatkan keterangan sebagai berikut:

"Pada masa sebelum kemerdekaan Kubu Babussalam merupakan negeri yang berdiri sebagai sebuah kerajaan pasai disaat itu, Kubu Babussalam dilanda kemarau panjang dan wabah penyakit yang mematikan seperti muntaber, Kolera, malaria, diare, campak, dan lain sebagainya. Sehingga tidak sedikit penduduk yang meninggal dunia. Hal itu terjadi ketika Datuk Rambai sudah lama wafat, dimana sebelumnya wabah penyakit dan bala tidak ada separah ini. Dikarenakan semasa beliau hidup, beliau selalu melakukan tolak bala serta doa dan mohon perlindungan kepada Allah agar masyarakat dan negeri kubu Babussalam diberikan keselamatan dan jauh dari mara bahaya serta wabah penyakit. Sepeninggalan beliau, masyarakat baru tersadar betapa berartinya sosok beliau ini. Maka untuk mengenang jasa - jasa beliau, masyarakat selalu melakukan ziarah kemakam Datuk Rambai dengan tujuan mendoakan beliau ataupun membayar niat, serta melaksanakan ritual tolak bala. Dengan adanya wabah penyakit yang melanda tersebut, maka masyarakat memutuskan untuk melakukan tolak bala. Dan benar saja, setelah itu hujan turun dan wabah penyakit pun berangsur hilang. Hingga saat ini tradisi itu masih dilaksanakan oleh masyarakat secara turun-temurun". ${ }^{5}$

Kedua, Pemimpin Ritual Tolak Bala. Ritual tolak bala dipimpin oleh seorang syekh atau mursid (KH. Anwar), yang harus memenuhi syarat serta mengetahui dan menguasai tata cara tolak bala tersebut. Paling tidak sudah pernah masuk suluk Thariqat Naqsyabandi. Pemimpin ritual tolak bala disebut dengan Atik oleh masyarakat kubu, dimana Atik ini didampingi oleh beberapa ustadz dalam ritual tolak bala yang bertugas membacakan ayat-ayat $\mathrm{Al}$ Qur ${ }^{\text {ee }}$ an setelah berzikir, 


\section{NUSANTARA; Journal for Southeast Asian Islamic Studies}

\section{Vol. 16, No. 2, Desember 2020}

dan juga terkadang membaca doa apabila sewaktuwaktu disuruh oleh sang Atik itu sendiri.

Ketiga, Prosesi Acara Ritual Tolak Bala. Pada hari dan waktu yang sudah ditentukan, yaitu pada hari keempat lebaran Idul Fitri atau ditanggal 4 Syawal. Pagi hari sekitar pukul 8 waktu setempat seluruh masyarakat yang turut serta ikut dalam ritual tolak bala mulai berkumpul ditempat yang sudah ditetapkan sebagai tempat pemberangkatan dalam ritual tolak bala ini. Peserta terdiri dari Atib (pemimpin ritual) beserta pendamping Atib, tokoh adat, tokoh agama, tokoh masyarakat, petinggi pemerintahan setempat, dan juga masyarakat yang keseluruhannya yaitu terdiri atas laki-laki semua.

Adapun peralatan yang di persiapkan adalah but (kapal kecil), nasi bekal makam siang dll. Adapun but (kapal kecil) itu sebagai kendaraan sungai yang di gunakan oleh masyarakat untuk melaksanakan ritual Tolak Bala Atib Ko Ambai, Pelaksanaan ataupun prosesi acara tolak bala ini hanya diikuti oleh kaum lakilaki saja, ini dikarenakan banyaknya alasan mengapa harus kaum laki-laki saja yang dapat ikut serta, dimana seperti yang telah ditambahkan oleh ust samsul bahri (selaku tokoh agama), ia mengatakan bahwa:

"Dalam acara Tradisi Ritual tolak bala Atib ko Ambai, memang laki-lakilah yang di anjurkan untuk ikut serta dalam pelaksanaan Ritual Tolak Bala tersebut, Sedangkan Perempuan diam di rumah, sehinggu Dahulunya perempuan di anjurkan untuk menutup pintu dan menjaga Anak-anak selama ritual Tolak Bala Atib Ko Ambai berlansung, serta di Anjurkan untuk dapat menghidupkan asap di depan rumah, Karena selama Ritual Tolak Bala berlansung, mereka berharap kepada Allah subhanahu wataala agar penyakit atau wabah yang menimpa kampung dan masyarakat di kecamtan Kubu Babussalam Allah angkat atau Allah hilangkan, dan tidak masuk kedalam rumah, begitu lah yang di anjurkan oleh para nenek moyang terdahulu yang mana sekarng sudah menjadi adat dan

\footnotetext{
6 Wawancara:KH. Ramli.( tokoh dari Tarikatt Naqsabandi) Pada Tangal 25 Januari 2021

7 Wawancara dengan KH. UST. Abdussalam Lc, MA. (pimpinan pondok pesantren Dar Aswaja) di Rumah nya Desa Sungai Pinang Tanggal 27 Desember, 2020 : Rottibul
}

budaya yang tidak boleh di tinggalkan oleh masyarakat kecamatan Kubu Babussalam)". ${ }^{6}$

Adapun proses rangkaian acara Ritual Atib Ko Abai dapat kita uraikan sebagai berikut :

1. Masyarakat tokoh Adat tokoh Agama dan pemimpin Ritual Tolak Bala Atib Ko Ambai yang ikut serta yang sudah tiba di dekat makom datuk rambai (syekh abdullah pasai) berkumpul dekat makom tersebut;

2. Di mulai dengan pembukaan dari panitia pelaksana dan di lanjutkan sambutan dari setiap tokoh dan camat;

3. Pemimpin Ritual Khotib Ketika itu di pimpin oleh KH. Syamsuar (mursyid atau guru dari toriqot naqsabandi ) memulai Ritual Tolak Bala Atib Ko Ambai dengan mengadiah kan Al-fatihah kepada Nabi Muhammad sollallahu 'Alaihiwasallam kepada syekh engku pasai kepada para waliyullah orang-orang Sholeh dll;

4. Selanjut Pemimpin Rotib mulai membacakan Dzikir-Dzikir yang sudah di tetap kan dari guru-guru terdahulu yang pernah memimpin Atib Ko Ambai Seperti Rottibul Haddad, Takhtim, tahlil, dll; ${ }^{7}$

5. Setelah selesai bacaan Dzikir dekat makom, Pemimpin Atib Ko Ambai Mulai berdiri untuk menuju ke but (kapal kecil) yang sudah siap di tepi sungai dekat makom, dan di kumandang kan azan yang di kumandang oleh 2 orang dari jamaah;

6. Setelah Azan selesai di kumandangkan Pemimpin Atib Ko Ambai mulai menuju But (kapal kecil) yang sudah di siapkan di ikuti oleh jamaah atau masyarakat sambil membaca tahlil (atib, istilah dalam toriqot naqsabandi oleh orang melayu di kubu babussalam);

7. Setelah pemimpin Atib Ko Ambai dan jam "ah nya masuk ke dalam But (kapal kecil) mulai lah But tersebut berjalan dan di belakang nya diiringi dengan But masyarakat, sambil membaca tahlil (Atib) bersama sama, mulai dari tepi Sungai dekat Maqom datuk Ramabai

Haddad merupakan Amalan yang berisi Doa dan Dzikir yang di susun oleh ulama asal Hadramaut Habib Abdullah bin Muhammad Al Haddad (1055-1132 H). Amalan ini Memiliki banyak Khasiat yang sangat dahsyat, sehingga kerap dijadikan Amalan rutin umat islam, termasuk di pesantren. 
(syekh abdullah pasai) sampai ke ujung sungai Kubu Babussalam (Kualo sungai) yang memakan waktu lebih kurang 2 jam;

8. Setelah sampai ke Ujung Sungai Kubu Babussalam (kualo sungai). Selesai lah bacaan Tahlil (atib) tersebut. Dan Di akhiri dengan Sholawat dan di tutup dengan Azan. Maka jamaecah atau masyarakat pun membuka makanan bekal yg sudah di siapkan sebelumnya, setelah itu masyarakat pun Pulang ke desa nya masing-masing dengan mengendarai But mereka Dengan Harapan Setelah Ritual Tolak Bala Atib Ko Abai ini di lakukan, jika ada penyakit atau wabah di kampung, agar Allah Angkat.

Prosesi dan tahapan tersebut merupakan Proses Ritual Tolak Bala Atib Ko ambai, Atib Ko Ambai menjadi ritual yang lestari dilaksanakan pada tiga hari setelah raya Idul Fitri di desa Teluk Nilap, kecamatan Kubu Babussalam, Kabupaten Rokan Hilir, ritual ziarah makam Syekh Abdullah Pasai seorang tokoh masyarakat penyebar Islam kedaerah tersebut memiliki keunikan berkumpul dan pergi ke makam dengan mengunakan pompong.

Tidak sekedar ritual biasa melainkan untuk menjaga tali silaturrahmi antara masyarakat desa sekaligus menolak bala.Dengan Melakukan doa kepada Allah (dengan cara Ritual tolak bala) berkat kesholehan datuk rambai (Syekh Abdullah Pasai) Meminta kepada Allah yang maha kuasa supaya Allah hilangkan wabah penyakit atau sesuatu yang meresahkan.

\section{Faktor-faktor yang menyebabkan masyarakat Kubu Babussalam melakukan Tolak Bala Atib Ko Ambai}

Dalam membahas data ini sebenarnya adalah proses analisis sebagai kelanjutan dari data display atau penyajian data setelah diredusi. Pada sub Bab sebelumnya telah disajikan data-data hasil wawancara dan observasi yang telah direduksi sebelumnya. Berikut ini pembahasan data yang diaplikasiikan dalam teori Kearifan lokal dan Teori difusi sosial. Sesuai dengan teori kearifan Lokal

8 Wawancara dengan Pak Atin (Camat Kubu Babussalam) di Kantor Camat, Tanggal 28 Desember 2020: Kualo Sungai Adalah Ujung Dari Sungai Kampung atau menurut Ataupah (2004, h. 54) kearifan lokal bersifat historis tetapi positif. Nilai-nilai diambil oleh leluhur dan kemudian diwariskan secara lisan kepada generasi berikutnya lalu oleh ahli warisnya tidak menerimanya secara pasif dapat menambah atau mengurangi dan diolah sehingga apa yang disebut kearifanitu berlaku secara situasional dan tidak dapat dilepaskan dari sistem lingkungan hidup atau system ekologi/ekosistem yang harus dihadapi orang-orang yang memahami dan melaksanakan kearifan itu.

Kearifan lokal merupakan produk budaya masa lalu yang patut secara terus menerus dijadikan pegangan hidup. Meskipun bernilai lokal tetapi nilai yang terkandung di dalamnya dianggap sangat universal. Kearifan lokal merupakan pengetahuan yang eksplisit yang muncul dari periode panjang yang berevolusi bersama-sama masyarakat dan lingkungannya dalam sistem lokal yang sudah dialami bersama-sama. Proses evolusi yang begitu panjang dan melekat dalam masyarakat dapat menjadikan kearifan lokal sebagai sumber energi potensial dari sistem pengetahuan kolektif masyarakat untuk hidup bersama secara dinamis dan damai.

Pernyataan ke ikut sertaan Informan atau masyarakat dalam melaksnakan tradisi tolak bala Atib Ko Ambai, semua Informan mengatakan pernah ikut serta melaksanakan tradisi tolak bala Atib Ko Ambai dan pernyataan faktor-faktor yang menyebabkan masyarakat Kubu Babussalam melaksanakan tradisi tolak bala Atib Ko Ambai sebagaiman yang dikatakan oleh pak Atin (camat Kubu Babussalam) sebagai berikut:

"Banyak faktor yang menyebabkan masyarakat dalam melaksanakan tradisi tolak bala Atib Ko Ambai. Masyarakat beranggapan jika traadisi Tolak Bala ini tidak di lakukan, di khawatirkan akan datang musibah, karna ini sudah menjadi tradisi tahunan dari nenek moyang kita, setidak nya walaupun kita tau musibah itu tidak akan ada kecuali atas kehendak Allah, dengan tradsi Tolak bala Ini, kita bisa melakukan doa bersama setiap tahunnya agar Allah jaga kampung kita dari musibah dan mara bahaya, akan tetapi kita

Sungai Kecamatan menuju Ke laut lepas atau laut Rokan Hilir. 


\section{NUSANTARA; Journal for Southeast Asian Islamic Studies}

Vol. 16, No. 2, Desember 2020

tetap berkeyakinan Allah lah yang mendatang musibah atau manfaat".

Pernyataan tentang prosesi pelaksanaan Tradisi Tolak Bala Atib ko Ambai, hampir semua informan menyatakan hal yang serupa, pernyataan tersebut seperti yang di katakan oleh KH. Ust. Abdussalam (pimpinan yayasan Dar Aswaja)

"pandangan saya tentang tradisi tolak bala ini boleh saja terus di lestarikan, selama pelaksaannya selalu di niatkan dengan niat yang baik, dan tidak melanggar norma norma Agama. Tradisi ini juga bisa menambah rasa solidaritas dan keakraban masyarakat kubu Babussalam, karena pada pelaksaan Ati Ko Ambai ini menjadi ajang silaturrahmi antara masyarakat Kubu Babussalam". ${ }^{10}$

Dari hasil analisis data yang peneliti lakukan ada beberpa Faktor yang menyebabkan masyarakat Kubu Babussalam melakukan Tolak Bala Atib Ko Ambai.

Faktor adat ataupun Budaya merupakan suatu faktor utama yang mendorong masyarakat untuk melaksanakan Tradisi Tolak Bala Atib Ko Ambai, karena masyarakat Kubu Babussalam mengaku Tradisi Tolak bala Atib Ko Ambai merupakan salah satu adat dan Budaya dari masyarakat Kubu Babussalam yang sulit untuk ditinggalkan. Masyarakat menganggap bahwa tradisi Tolak Bala sebagai adat dan Budaya yang memang sudah sejak dahulu dilaksanakan oleh para ulama-ulama dan tokoh Adat serta Pemerintah setempat di Kecamatan Kubu Babussalam Khususnya dan ulama-ulama Nusantara.

Melalui faktor fanatik, seoalah-olah Tradisi Tolak Bala dapat mempengaruhi masyarakat dalam proses pelaksanaannya. Masyarakat turun temurun melaksanakan Ritual tersebut. Pengaruh turuntemurun tersebut masyarakat menganggap Tradisi Tolak Bala itu baik apabila dilaksanakan, Dari faktor-faktor tersebut, masyarakat sulit meninggalkan Tradisi Tolak Bala, walaupun ada yang mengatakan tidak di benarkan melakukan Tradisi Tolak Bala karena dapat mengundang kesesatan, namun Tradisi tolak Bala tetap dilakukan diberbagai lapisan masyarakat dalam

\footnotetext{
${ }^{9}$ Wawancara : pak Amat Atin (camat kecamatan Kubu Babussalam) di kantor camat, tanggal 14 januari 2021.
}

acara tertentu. Adapun pandangan masyarakat terhadap Tradisi Tolak Bala yaitu bisa membawa umat manusia kepada keberkatan dengan berkeyakinan bahwasan nya Allah lah yag mendatang kan keberkatan tersebut, dan bisa pula menjerumuskan umat manusia kepada kemusrikan jika beranggapan atau berkeyakinan adat atau kuburan dan benda-benda lainnya yang menyebabkan manfaat atau moderat nya tidak menimbulkan pengaruh apapun terhadap kehidupan umat manusia selama masih menjaga aqidah yang dianutnya.

\section{Hubungan antara Islam dengan Tradisi Tolak Bala Atib Ko Ambai}

Hubungan antara Agama Islam dengan tradisi Tolak Bala Atib Ko Ambai bisa menimbulkan tiga kemungkinan besar, yaitu tidak bertentangan, harmonis, dan bertentangan.

Pertama, tidak bertentangan. Hubungan antara Islam dengan Tradisi Tolak Bala Atib Ko Ambai dikatakan tidak bertentangan karena selama ini masyarakat menerima pendidikan terhadap tradisi Tolak Bala Atib Ko Ambai itu dari lingkungan tempat ia tinggal. Kemudian Tradisi Tolak Bala Atib Ko Ambai dilaksanakan oleh masyarakat dipandu oleh Tuan guru dari Tarikat Naqsabandi dan di akui oleh majlis ulama setempat dan di dukung oleh pemerintah setempat. diiringi dengan doa-doa yang sering digunakan dalam ajaran Islam, dan Tradisi Tolak Bala Atib Ko Ambai sudah menjadi sebagian dari kehidupan masyarakat Kubu Babussalam yang belum pernah ditinggalkan, walaupun dikalangan masyarakat yang bertentangan dengan tradisi Tolak Bala. Sehingga masyarakat menganggap Tradisi Tolak Bala tidak bertentangan dengan Agama Islam.

Kedua, Harmonis. Hubungan antara masyarakat Islam dengan Ritual Tradisi Tolak Bala Atib Ko Ambai menciptakan keharmonisan karna Masyarakat menganggap hubungan antara agama Islam dengan tradisi Tolak Bala Atib Ko Ambai selama ini tidak ada masalah, sebab masyarakat belum pernah menyaksikan terjadinya perdebatan atau konflik atas perselisihan pendapat terhadap tradisi Tolak Bala di Kalangan Masyarakat Kubu

10 Wawancara : KH. Ust. Abdussalam (Pimpinan Yayasan Dar Aswaja) Di kediaman nya Desa Sungai Pinang, 7 Januari 2021. 
Babusslam. Oleh karna itu tradisi tolak bala Atib Ko Ambai tetap berlansung dan di lestarikan sampai sekarang.

Ketiga, Bertentangan. Tradisi Tolak Bala Atib Ko Ambai bertentangan dengan Aqidah Islam, apabila masyarakat mengkhawatirkan jika tradisi tolak bala tidak di laksanakan maka akan terjadi bencana dan wabah lain nya (berkeyakinan Ritual Tolak Bala tersebut yang menetukan segala sesuatu itu terjadi), maka masyarakat yang belum mampu mengenal antara Adat dan aqidah akan terjerumus kepada kemusrikan. Hal ini disebabkan seolaholah tradisi Tolak Bala Atib Ko ambai dapat membawa keuntungan, jika tidak mengikuti dan merayakan Tradisi Tolak Bala maka akan menimbulkan bencana. Dari anggapan tersebut justru mengundang kesesatan bagi umat manusia sehingga memudahkan umat manusia mempersekutukan Tuhan yang maha Esa.

Masyarakat Kubu Babussalam sampai saat ini masih melaksanakan tradisi Tolak Bala Atib Ko Ambai sebagaimana mestinya dilaksanakan pada masa lalu, memang saat ini arus perkembangan zaman sangat pesat dan masyarakat mengkhawatirkan tradisi Tolak Bala Atib Ko Ambai akan hilang dari kehidupannya. Anggapan masyarakat jika Tradisi Tolak Bala Atib Ko Ambai itu dihilangkan dari kehidupan maka sedikit orang yang merespon terhadap hal tersebut karena masyarakat sudah sibuk dengan hal-hal yang modernisasi dengan mudah memperoleh kenyataan. Masyarakat sudah sangat percaya tentang hal tabu yang terus menerus berkembang tentang efek yang timbul dikemudian hari jika tidak Tradi Tolak Bala Atib Ko Amabai tidak di lakukan setiap tahun nya.

\section{Kesimpulan}

Datuk Rambai adalah seorang pengembara yang berasal dari daerah Aceh datang ke Kubu bersama pengikut dan beberapa muridnya dengan maksud dan tujuan untuk mengembangkan ajaran agama Islam yang sebenarnya didaerah Kubu. Yang dimana beliau bernama Teuku Abdullah Pasai dan beliau wafat didaerah Kubu yang sekarang bernama Desa Teluk Nilap, serta masyarakat setempat menyebut nama dan makam beliau ini sebagai sekarang.
Pada pelaksanaan Tradisi Ziarah Makam Datuk Rambai terdapat beberapa hal penting yang terbagi atas dua pelaksanaan tradisi ziarah didalamnya, yaitu; Tradisi Ziarah Makam Datuk Rambai dalam acara ritual tolak bala, serta Tradisi Ziarah Makam Datuk Rambai dalam membayar niat (bernazar).

Tradisi Ziarah Makam Datuk Rambai dalam acara ritual tolak bala dilaksanakan sekali dalam setiap tahunnya pada saat hari keempat Idul Fitri. Yang dimulai dari pukul 8 pagi hingga selesai, dengan tujuan untuk menolak bala serta membuang segala bentuk hal-hal buruk dan juga penyakit ke laut.

Pemimpin ritual tolak bala disebut dengan Atik oleh masyarakat kubu, dimana Atik ini didampingi oleh beberapa ustadz dalam ritual tolak bala yang bertugas membacakan ayat- waktu disuruh oleh sang Atik.

Perlengkapan dan peralatan dalam acara ritual tolak bala ini ialah berupa bekal atau bokal dalam bahasa setempat yang berisikan nasi beserta laukpauknya, air mineral/air minum, mikropon atau pengeras suara, umbul-umbul atau bendera warna-warni, serta yang paling utama yaitu pompong (perahu motor) sebagai media kendaraan dalam pelaksanaan acara ritual tolak bala.

Tradisi ziarah makam Datuk Rambai dalam membayar niat (bernazar) biasa dilaksanakan oleh masyarakat yang mempunyai niatan/nazar saja yang sifatnya perorangan ataupun dalam cakupan kecil saja. 7. Sistem nilai tradisi ziarah makam Datuk Rambai ini terdiri atas beberapa aspek yang tergambar pada Nilai Sejarah, Nilai Simbol pada Kain Putih, Nilai Keagamaan (Religius), dan Nilai Kekeluargaan. 


\section{DAFTAR PUSTAKA}

Abdullah, Irwa, Kontruksin dan Reproduksi Kebudayaan, Cet,I; Yogyakarta Pustaka Pelajar. 2006

Arinkunto, Suharsimi. 2006. Prosedur Penelitian Suatu Pendekatan Praktek Jakarta:Rineka Cipta

Begum Aisyah Badawy, Mengenal Islam Selayang Pandang, Bumi Aksara, Jakarta, 1994,

C.A. Van Peuresen, Strategi Kebudayaan, (Yogyakarta: Kanisisus, 1998),

Departemen Pendidikan dan kebudayaan, kamus besar bahasa indonesia, Tim Penyusun Kamus Pusat Pembimbing dan pengembangan Bahasa, Balai Pustaka, Jakarta 1994,

Islami dan Iksanudin. 2014 Simbol dan Makna Ritual Yaqowiyu di Jatinom Klaten. Dalam Jurnal Media Wisata

Juliansyah Noor, Metode Penelitian: Skripsi, Tesis, Desertasi, dan Karya Ilmiah, Jakarta: Kencana, 2011)

Koentjaraningrat, Beberapa Pokok Antrapologi Sosial, (Jakarta: Dian Rakyat, 1985),

KH. Ramli, Wawancara di Lakukan Pada Tangal 31 Mei 2020

Manfred Ziemek, pasentren Dalam Perubahan Sosial, P3M, Jakarta, 1986 Mursal Esten. Kajian Transformasi Budaya. (Bandung:Agkasa, 1999).

Moh. Nur Hakim" Islam Tradisional dan Reformasi Pragtisme" agama dalam pemikiran Hasan Hanafi (Malang: Bayu Media Publishing, 2003)

Sugiyono, Jhonthan. 2006 Metode Penelitian Kuantitatif, Kualitatif dan R\&D. Bandung:Alfabeta

Ust. Samsul, Bahri. Wawancara Diakukan Pada Tangal 31 Mei 2020 